\title{
The Human Security Dimension of China's Belt and Road Initiative
}

\author{
Rosita Dellios ${ }^{1} \&$ R. James Ferguson ${ }^{1}$ \\ ${ }^{1}$ Faculty of Society and Design, Bond University, Gold Coast, Australia \\ Correspondence: Rosita Dellios, Faculty of Society and Design, Bond University, Gold Coast 4229, Queensland, \\ Australia. Tel: 61-7-5595-2514. E-mail: rdellos@bond.edu.au
}

Received: June 20, 2017

Accepted: July 10, 2017 Online Published: August 3, 2017

doi:10.5539/jms.v7n3p48

URL: http://doi.org/10.5539/jms.v7n3p48

\begin{abstract}
Despite the geopolitical calculations associated with China's Belt and Road Initiative, and how this will allow Beijing greater influence in transregional relations, the human security dimension goes to the heart of China's wider regional strategy. The importance of development cannot be understated even as the "rise of China" attracts the headlines. How well Beijing can engage wider human security concerns will be crucial for the success of this megaproject. It is argued that the human security aspect of China's Belt and Road Initiative requires a stronger ethical base - one which draws on China's own Confucian heritage. This allows for both cultural inclusiveness and the promotion of higher levels of trust towards Beijing's policies and intentions.
\end{abstract}

Keywords: Chinese foreign policy, Belt and Road Initiative (BRI), One Belt One Road (OBOR), human security, Confucian values

\section{Introduction}

As the People's Republic of China (PRC) increases its influence and leadership through the new silk roads known as the Belt and Road Initiative, the question of human security will come under greater scrutiny. The purpose of this article is to argue that the Chinese government should emphasize human security as a key component of silk roads development, while also enhancing the concept's Western defined legitimacy with the insights of Confucian thought. Within Confucian teachings may be found a sophisticated concept of human relations based on core ideas of benevolence (ren), social customs $(l i)$, reciprocity $(s h u)$ and harmony $(h e)$. This is a challenge that looms before Beijing's regional architects of prosperity and connectivity. An investigation of human security as a central concept of this article is followed by an overview of the new silk roads, their significance in light of the historic "tribute system" (asymmetrical relations supporting China's primacy), and China's diverse relational models. Here the application of Confucian philosophy may be seen as the best policy for the "cultural inclusiveness" expressed in official articulations.

\section{What is Human Security?}

Human security focuses on individuals, families, local communities and indigenous groups who face a wide range of threats, including natural disasters, environmental collapse, poverty, and civil war (Lizee, 2002). The UN General Assembly Resolution 66/290 on Human Security (2012), sponsored by Japan, states that the notion of human security includes:

(a) The right of people to live in freedom and dignity, free from poverty and despair. All individuals, in particular vulnerable people, are entitled to freedom from fear and freedom from want, with an equal opportunity to enjoy all their rights and fully develop their human potential

(b) Human security calls for people-centred, comprehensive, context-specific and prevention-oriented responses that strengthen the protection and empowerment of all people and all communities

(c) Human security recognizes the interlinkages between peace, development and human rights, and equally considers civil, political, economic, social and cultural rights

Human security has been a central developmental agenda within the United Nations Development Programme (UNDP) from 1994. Human security also forms a major part of Canadian and Norwegian foreign policy and serves as a key guiding principle in Japan's Development Cooperation Charter (developmental aid). In the case of Japan, human security was one of the four key areas guiding development cooperation from 2015, outlining priority aid corridors in East and South Africa, along with strategic master plans being developed for South and West Africa. It thereby helped implement the Yokohama Action Plan (2013-2017) with human security achieved 
through promoting economic growth, infrastructure capacity, empowering farmers, promoting sustainable, resilient and inclusive growth, and consolidating "peace, stability, democracy and good governance" (MOFA, 2015). Japan is among the top four aid and developmental donors globally, providing some \$6.3 million in ODA in 2015, thereby funding human security agenda as well as enhancing Japan's soft power (JICA, 2016).

The human security framework has developed an extensive literature, along with critical viewpoints that show that this approach cannot be used effectively in a mechanistic way. It is regularly deployed in foreign policy analysis, as well as in the context of human rights and human development more widely conceived. It has been seen as particularly applicable as a governance "checklist" for countries with ongoing political insecurity and failures to address a range of non-traditional security threats, including climate change, refugees and "irregular migration", environmental damage, transnational crime and transnational health threats (Teh, 2012; Acharya et al., 2011; Okubo \& Shelley, 2011). Human security has gained widespread recognition as a persuasive concept to orient security toward individuals and re-inforce human-centred policies. However, building an all-inclusive and comprehensive human security approach remains elusive and difficult to operationalize, especially in conflicted political settings or in state-centric nations (Newman, 2016; Caballero-Anthony, 2015; Tzifakis, 2011). Nonetheless, sustained efforts to establish a functional knowledge of human security insights have continued. These have led to major projects in Latin America (run in part through the Inter-American Institute of Human Rights), related interventions channelled through the United Nations Office for the Coordination of Humanitarian Affairs (OCHA) and the UNDP, the production of regular human security reports (through the Human Security Report Project, 2005-2013), the publication of the Human Security Indexes and the conceptually related Fragile States Index, as well as the publication of various human security handbooks (Human Security Unit, 2016; Schirch, 2015).

Human security links directly to development and peace in various ways. This is because a low level of development correlates with higher insecurity. The Human Development Index (HDI), which uses life expectancy, income and education factors, equates, when low, with a lack of human security. In one estimate, societal and political violence, with related military, policing and peacekeeping costs had an estimated total economic impact of over $\$ 13.6$ trillion in 2015 , approximately $13.3 \%$ of world GDP, thereby hampering government capacities, developmental policies and aid outcomes (IEP, 2016). This is associated with potential instability that can undermine peace. In de-emphasizing state security, human security is compatible with development but can provide a "back door" towards human and ethnic rights within states. For this reason it is treated cautiously by China with its history of ethnic uprisings - notably Tibetans and Muslim Uighurs - and subsequent repressive measures.

There are other problems with the concept of human security besides the objections made on behalf of state security, as in China's case. First, human security tends to securitize deep developmental issues and creates a sense of threat in relation to social and economic problems. Second, it can become too inclusive and costly, unless priorities are clearly established. Third, it has the capacity to undermine, indirectly, human rights achievements. This can occur by widening the agenda of interests driven by external groups, such as the developed states' concern with transnational migration, drug flows, or organised crime. Consequently, human security can be an international policy tool used by the Global North against a seemingly unstable Global South. This accentuates an asymmetric system that sees "powerful (central) states exercising human security prerogatives towards weak states", with the consequence of negative labels, such as such as "fragile" or "failed" state-sometimes being used prematurely (Thede, 2008). Fourth, there is real but limited support for the notion human security. Canada, Norway, Japan, and the European Union are viewed as its main supporters but, as noted above, there is a more cautious approach by China; so, too, by Russia (Shevchenko, 2013). Though China has not adopted this schema formally, it has led to ongoing debates in China in a "Sinicized" form whereby the state should protect its population from a range of non-traditional threats. This has been articulated in PRC's regional relations, for example via the Joint Declaration on Cooperation in the Field of Non-traditional Security Issues (2002) with ASEAN, in the ACCORD (ASEAN and China Cooperative Operations in Response to Dangerous Drugs) agreements of 2000 and 2005, and in recent PRC white papers and policy documents (PRC, 2017a; PRC, 2017b; Emmers, 2007; Wong, 2007; Lijun, 2006). However, these concerns have not flowed into a wider pattern of civil society empowerment (Ren, 2016; Breslin, 2015; Wu, 2012).

Finally, there arises the question of interpretation as to what human security is. Not everyone agrees with the way it is framed even though it has been delegated as an international norm. In his critique of Japan's official discourse on human security from 1998 to 2008, Kamil Abt (2013, p. 216) found that:

...human security was represented as having evolved rather than being the product of political contest, the consensus said to be characteristic of relations between agents of human security was framed as having 
emerged; implying a natural and uncontested process. The representation of relations between agents of human security in terms of consensus functioned to legitimate policy through an appeal to shared interests and thus a rejection of parochialism.

One may conclude that one person's (or agent's) "parochialism" is another's cultural diversity. It is from here that the more noble sentiments of the Belt and Road Initiative may find justification, as well as the cautionary tale that "one size does not fit all". Moreover, not only is the parochial in all its cultural difference of interest here, but also the freedom of an individual to discern what their own human security entails - rather than be informed of this by government policy. As Abt (2013, pp. 55-56) points out, if human security is "based on the idea that individuals should be able to make their own choices", then there is "a logical incompatibility that could de-legitimise the pursuit of human security, if individuals chose not to accept the terms of policy... or if they made choices which were incompatible with the concept of human security as defined by Japan".

Human security, then, needs a serious consultative and grass-roots component to avoid undermining small communities, their economic sustainability and diverse values. Large, top-down projects designed in Beijing or negotiated in Asian capitals may easily become top-down transformations that only belatedly factor in local conditions and social impact. Let us now turn to the new silk roads project to understand how human security fares in this ambitious plan to transform whole regions and their diverse populations.

\section{What are the New Silk Roads?}

The new silk roads are so named as an evocative reference to the old caravan trade routes in which Chinese silk was a major commodity. There were other commodities and many trade routes, including those by sea and not only land, involving Arabs, Indians, and Southeast Asians, to name but a few. It was a German, Ferdinand von Richthofen, who coined the term Silk Road (or Roads) in the 19th century. This has now become shorthand for more than the original system of overland caravan routes. The new silk roads traverse three continents, two seas and two oceans. The continents are Asia, Europe and Africa, with the Middle East connecting all three. Their maritime counterparts are the South China Sea, the Mediterranean Sea, the Indian Ocean and the Pacific Ocean's southern sector.

More specifically, the new silk roads refer to the overland "Silk Road Economic Belt", which Chinese President Xi Jinping announced in Kazakhstan in September 2013, and the "21st Century Maritime Silk Road" that he launched as a plan of economic cooperation a month later in Indonesia. (See Appendix A for a map of the new silk roads.) These land and sea routes became known as OBOR (One Belt One Road) and by 2015 were simply referred to as the Belt and Road Initiative (BRI). Like the original "silk road", there was always more than one. The PRC sees this as an evolving initiative that will engage new states, partners, sources of funding and projects over coming decades.

As explained in the government document, Vision and Actions on Jointly Building Silk Road Economic Belt and 21st-Century Maritime Silk Road (National Development and Reform Commission-NDRC, 2015), there are at least five "roads", "connecting the vibrant East Asia economic circle at one end and developed European economic circle at the other, and encompassing countries with huge potential for economic development" (NDRC, 2015, III. Framework, para 2). These five are (see also Hong Kong Trade Development Council-HKTDC, 2016, p. 1):

1) The China-Europe land route via Central Asia and Russia

2) The China-Europe sea route via the South China Sea and Indian Ocean

3) China-Middle East via Central Asia

4) A route linking China, Southeast Asia, South Asia and the Indian Ocean

5) China-South Pacific via the South China Sea

Within the five roads are six economic corridors (NDRC, 2015, III. Framework, para 3; see Appendix B for a map of the economic corridors):
1) Eurasian Land Bridge
2) China-Mongolia-Russia
3) China-Central Asia-West Asia
4) China-Indochina Peninsula
5) China-Pakistan
6) Bangladesh-China-India-Myanmar 
While economic cooperation is to be applauded, what of human security concerns? Here, the Vision and Actions document $(2015$, IV. Cooperation Priorities, paras 13, 14) is clear in its position. It is one that takes a broad ecologically-based view on the one hand and attention to "local livelihood" on the other-areas that deserve a sustained focus:

We should promote ecological progress in conducting investment and trade, increase cooperation in conserving eco-environment, protecting biodiversity, and tackling climate change, and join hands to make the Silk Road an environment-friendly one.

We welcome companies from all countries to invest in China, and encourage Chinese enterprises to participate in infrastructure construction in other countries along the Belt and Road, and make industrial investments there. We support localized operation and management of Chinese companies to boost the local economy, increase local employment, improve local livelihood, and take social responsibilities in protecting local biodiversity and eco-environment.

A wide range of funding mechanisms will be needed for progress on these roads and corridors. Funds from the $\$ 40$ billion Silk Road Infrastructure Fund are being dedicated to early-start projects, with further investment from the BRICS New Development Bank and the China Development Bank. Extra funds may be mobilized from the Export-Import Bank of China, China's Energy Development Fund and other Chinese institutions (Kynge, 2016; Preston, 2016). The China-ASEAN Investment Cooperation Fund (circa \$20 billion), the China Construction Bank, and Agricultural Development Bank of China (ADBC) will also have roles to play. Likewise, China's sovereign wealth fund (circa $\$ 746$ billion) and its strong foreign exchange reserves (circa $\$ 3.16$ trillion as of September 2016), might be used to invest in higher yielding assets than US Treasury Bonds (Grieger, 2016; Preston et al., 2016). One of the key financial backers of the Belt and Road Initiative is the $\$ 100$ billion Asian Infrastructure Investment Bank (AIIB). Initiated by China it is now operational with 57 member nations. According to its website (2014-2016), the AIIB "will put in place strong policies on governance, accountability, financial, procurement and environmental and social frameworks".

China's National Planning on the BRI does not formally mobilise the concept of human security, but addresses several related security issues. It links environment with social policy to "meet the challenges of sustainable development in Asia". There are a number of objectives within its Environmental and Social Framework (AIIB 2016, p. 2), including aspirations to:

- Ensure the environmental and social soundness and sustainability of Projects.

- Provide a mechanism for addressing environmental and social risks and impacts in project identification, preparation and implementation.

- Provide a framework for public consultation and disclosure of environmental and social information in relation to Projects.

- Improve development effectiveness and impact to increase results on the ground, both short- and long-term.

- Facilitate cooperation on environmental and social matters with development partners.

Recent research has begun to frame related security concerns for the BRI. The Maritime Silk Road itself can be seen as an effort to safeguard China's energy access by ensuring security of its sea lines of communication (SLOCs), as well as alternative continental corridors that link onto ports on the Indian Ocean that sideline the Malacca Strait (Len, 2015). Beyond extended access to resources in Central Asia and Russia, the diverse corridors within the BRI include strategic planning to boost local energy production, providing the backbone for infrastructure and industrial development. Thus the Visions and Actions planning framework explicitly includes the plan to build new integrated industrial chains based on nearby energy sources, both conventional and renewable. The China-Pakistan Economic Corridor itself will develop power and transportation networks, including coal, hydro, wind and solar sources (Uberoi, 2016; Dong, et al., 2016; Snelder, 2016; Preston, et al., 2016). Likewise, wider Eurasian projects will include the building of up to 30 nuclear power plants by 2030 (Freiman, et al., 2016). A central logic of the new silk roads project is that a wider framework of geopolitical security can be achieved by embracing shared economic growth combined with resource and energy security (Fallon, 2015).

Awareness is growing of the environmental impact and implications of the BRI, including water and ecological security in Central Asia and the Tarim Basin, with increased desertification due to excessive water usage (Chen et al., 2016). China has already found this a serious challenge to its internal Great Western Development project. Water accessibility in Xinjiang, for example, as indicated by water available per capita (surface and ground water), has declined by $30 \%$ through $2010-2014$, with concerns that climate change will continue to reduce 
glacial melt flows crucial for the region (NBS, 2016; Millward, 2007). It is realised that poverty reduction may come at the cost of increased environmental degradation, unless the balance between ecological integrity and economic growth can be ensured ( $\mathrm{Li}$ et al., 2017). The BRI therefore needs to embrace enhanced scientific research, data collection, and international collaboration to reach sustainable management practices based on international collaboration ( $\mathrm{Li}$ et al., 2015). Related health factors, including the spread of HIV due to increased mobility, have also found a place in recent research (El-Bassel et al., 2016).

However, these diverse approaches do not add up to a comprehensive analysis of the human, societal and environmental impacts of the evolving BRI project. Nor does it provide a normative rationale for the PRC as a major power shaping the well-being and daily life of millions of people beyond its borders. Perhaps it is in the spirit and not only the detail of the Belt and Road Initiative that an ideational component can be gleaned when the Vision and Actions document (2015, III. Framework, para 1) speaks of "cultural inclusiveness".

\section{A New Tribute System?}

If the Belt and Road Initiative emerges as one of China's historic grand projects, then it would have more in common with the cultural inclusiveness of the tribute system than the defensive and exclusionary Great Wall. The former crossed borders to interact with the world beyond the Chinese empire; the latter demarcated a border between the Han Chinese within and non-Han peoples outside this domain, but seeking to control flows and interactions across the wall. It is worth noting, however, that during the Han dynasty (206 BCE-220 CE) the Great Wall was extended westward to protect trade - and with it the flow of ideas and cultures — along the Silk Road.

The tribute system reached its most celebrated heights during the 15th century Ming voyages of Admiral Zheng He. It allowed China to extend its influence as far afield as South Asia and Africa. It also provided a moral-cosmological compass of its ideal world order: one in which the Celestial Empire was the upholder of harmony in relations with non-Han peoples beyond the Great Wall and kingdoms across the seas. The tribute system spanned centuries of imperial rule, whereby the Chinese empire would trade only with those kingdoms that it recognized as tributary subjects. The demise of the system came with the imposition of the Westphalian international order after China's defeat by Britain in the 19th century Opium Wars.

The new silk roads may come to represent a return to Chinese-oriented international relations, without losing the features of sovereign equality that distinguishes the Westphalian system from the traditional tribute system of hierarchical or asymmetric relations. (Note 1) But like the older system, the current one will channel ways of thinking along its paths of trade, representing a recalibration of global politics to enhance South-South relations. These often emphasise development, but also political and cultural diversity.

The BRI also foreshadows a return to the pivotal role of Eurasia and the Indian Ocean. The importance of Eurasia may be appreciated in the emergence of three rising (or resuming) powers - China, India and Russia —as well as regional organizations such as the Shanghai Cooperation Organization (SCO) and its recent complementary counterpart, the Eurasian Economic Union (EEU). (Note 2) As to the maritime importance of the Indian Ocean, this is reflected in the recent shift in terminology from the "Asia-Pacific", a term that takes in the Americas, to the increasingly popular "Indo-Pacific" that embraces the Indian subcontinent, eastern Africa and the Middle East. American, Japanese, Australian and Indian foreign and defence policies increasingly recognize the growing significance of the Indo-Pacific as a focus of economic growth and emerging security concerns. One may even speak of an Indo-Eurasian sphere that begins in China, travelling across land and sea until it meets in Europe (detailed below). Beijing, as the author of this grand plan, would have stronger influence in transregional relations, greater economic clout and resource access as well as infrastructure that could be used in projecting its power. Countries in BRI networks have major global resources: over $15 \%$ of global oil; over $50 \%$ of global gas, $25 \%$ of coal, $20 \%$ of iron ore, plus considerable resources of bauxite, zinc, copper and nickel. PRC in turn has become a dominant primary resource importer for countries such as South Sudan, Sudan, Turkmenistan, Mongolia, Laos and Iran (Preston et al., 2016). China has already begun expanding port capacities across the Indo-Pacific at Kyanukoyu, Chittagong, Payra, Hambantota, Colombo, Gwardar, Djibouti, Bagamoyo and Beira, facilities that could be used not just for trade but for China's expanding navy (Tweed, 2016; Albert, 2016).

The current discussion is still embryonic and largely about ports, pipelines, railways and connectivity. It is the human security dimension that awaits further articulation and action. Without this facet, the BRI risks degenerating into mere rhetoric. Worse still, it would represent a setback for eco-social development and hence the foundations of human security. If it succeeds, however, the impact of this transregional development plan would well deserve the status of a historic grand project that contributes to balanced human development on a global scale. 
A test case for whether China has embarked on the negligent negative scenario or is veering towards a more positive trajectory is its relationship with neighbours today, especially in the more contested maritime areas. Smaller countries like the Philippines and Vietnam that have competing claims with China over the South China Sea might have had occasion to celebrate when the Permanent Court of Arbitration at The Hague ruled against China's claims in the South China Sea in July 2016. But they needed Chinese investment and inclusion in BRI to lift living standards. Vietnam had already been promised investment in education and health, as well as half a billion dollars for infrastructure (Clark, 2016; Dellios, 2016). So too the Philippines, which originally brought the case against China in 2013, has sought development. Filipino business groups had hoped to gain from BRI's Southeast Asian projects, with Chinese coastal regions such as Fujian and Guangdong being viewed as hubs for further mutual development between China and the Association of Southeast Asian Nations (ASEAN) (Tiquia, 2015). Yet despite the legal win in July 2016, Filipino fishermen had initially remained the losers as the China Coast Guard continued to deny them entry into the disputed area of Scarborough Shoal, also known as Panatag Shoal - their traditional fishing grounds.

Here lay a human security issue that went to the heart of China's wider regional strategy: would small communities with a single lifeline of survival be swept away in grand visions of belts, roads and corridors? As matters turned out, the answer is "no", but in the case of the Philippines, this was more a by-product of political relations and the Chinese quest for influence. Philippine President Rodrigo Duterte, unlike his processor who took the South China Sea case to court, embarked on a foreign policy shift to China. When he visited Beijing in October 2016, Duterte declared before an audience of 200 businesspeople his "separation" from the United States - though he later clarified that this did not entail the severance of diplomatic ties (Reuters, 2016). Three months later, a Philippine cabinet delegation visited China and came away with a Chinese agreement to "cooperate with the Philippines on 30 projects worth $\$ 3.7$ billion focusing on poverty reduction" (Reuters, 2017). Meanwhile, Philippine fishermen were able to return to their traditional fishing areas. According to an official statement from Manila: "The Chinese leader [vowed] that the fishermen will continue to have free access to their traditional fishing grounds, apart from offering them training such as in fish culture to sustain their livelihood and families" (Philippine Presidential Communications Office, quoted in SCMP, 2016).

Additionally, the Philippines proposed protecting a fish-spawning lagoon within Scarborough Shoal (AP, 2016). This would contribute to the sustainability of fish stocks in an already over-fished sea. It represents an environmental factor impacting on people's livelihoods, and hence a human security issue worthy of China's support. These ideas were further developed in the PRC's June 2017 Vision for Maritime Cooperation under the Belt and Road Initiative, which spoke of "setting up the all-dimensional, multi-tiered and broad-scoped Blue Partnership, jointly protecting and sustainably utilizing marine resources to achieve harmony between man and the ocean for common development and enhancement of marine welfare." (PRC, 2017b). Linked to the UN 2030 Agenda for Sustainable Development and the China-ASEAN Environment Cooperation Strategy and Action Plan, this agenda proposed the setting up of carbon sinks, coastal eco-system monitoring, joint marine disaster warning systems, and related colleges, institute and monitoring centres (PRC, 2017b). If followed through, this Blue Partnership will do much to assuage environmental and human security concerns related to BRI as a whole. This is not only a matter of promoting China's strategy of winning over support from neighbours wary of Chinese ambitions in the South China Sea, but also speaks directly to Chinese traditional values - those of Confucianism - that are both universal in scope and applicable in the area of human security.

\section{A Confucian Interpretation of Human Security}

Several factors have been identified as having a core role in historical Chinese and Confucian conceptions of good government. These include a focus on the well-being of the people, the ability to feed and educate them, avoidance of unnecessary wars and limitations on the use of harsh punishments (Confucius Analects VI.30 \& XII.7; Mencius Mencius VIIB.4; Jia Yi New Writings in de Bary \& Bloom, 1999, pp. 290-292). Mobilizing them with effective leadership, based on moral exemplars and the choice of effective officials, ideally results in a meritocratic society and enhances state legitimacy (Confucius Analects XIX.10; Bell, 2015; Yan, 2011). These pragmatic orientations thus contained the seeds of security conceived as based on the people's welfare, including food security, thereby reducing societal fear and insecurity. Though rarely practised in full, these aspirations provided a framework for an expanding sphere of Chinese influence in which central governments were able to manage the demands of huge rural and growing urban populations. Sophisticated relational concepts - both for domestic governance and international relations-evolved at the same time, including notions of balance, reciprocity, harmonization of difference, benevolence as mutual recognition, and the transformative role of culture in foreign relations (Confucius Analects IV.15; Lewis, 2009; Zhao, 2006; Dallmayr, 2003; Ames \& Hall 2000). Chinese and Western commentators have seen these as key enabling factors for the survival of China over 
three millennia, though not leading towards democratic or fully developed political rights (Zhang, 2010; Morton \& Lewis, 2004; Ferguson \& Dellios, 2017).

How does this relate, one may ask, to the above example of China and its smaller neighbours exploring maritime cooperation and poverty reduction in the Philippines? Consider the Confucian take on the universal golden rule: $s h u$ (reciprocity, kindness). In Christianity this is expressed as a positive state of affairs: Do unto others as you would have them do unto you. In the teachings of China's best known philosopher, Confucius (551-478 BC), it is expressed in the negative: "Do not impose on others what you yourself do not desire" (Analects, 15, p. 12). Empathy as the essence of Confucian humanism therefore takes a less invasive approach to human affairs. Human security, when viewed through the lens of Confucian thought, may allow for greater self-determination. This is not to be confused with government policies which can be at odds with the teachings of Confucius. East Asian states with a Confucian heritage, including Japan, are not necessarily better at showing empathy and non-interference with regard to their own citizens, irrespective of the political system in place. It is in this context of possibility rather than pessimistic expectations that the Belt and Road Initiative can be addressed.

The above-noted story of the Filipino fishermen being denied access to their Scarborough Shoal fishing grounds, despite an international court ruling, has developed in the direction of reciprocity by not impinging on the freedom of local fishermen. Likewise, tense stand-offs between Indonesian fishery patrol boats and Chinese vessels over "traditional fishing grounds" near the Natuna Besar Island in March 2016 led to Indonesian diplomatic protests that were only eased by mutual restraint and an emphasis on the wider, positive relationship between the two countries (Supriyanto, 2016a, 2016b). A long-term resolution of these claims will need to be developed if China's BRI and Indonesia's "Global Maritime Nexus" (a comprehensive empowerment of maritime resources and security) agenda are to become fully compatible.

While such reciprocity makes sense in the field of diplomacy, in Confucian terms it is deeply ingrained. The Confucian rendering of interdependence flows from the concept of ren (benevolence, humaneness) which comprises the characters: 人 meaning "person" and 二 meaning "two". Humaneness, based on the experience of interacting with other people, requires $l i$ (social customs, rites) as its outer expression. $L i$ articulates proper (considerate) behaviour towards others. Translated to international relations it speaks to the need to build trust. The criticism that this could amount to little more than "empty ritual" and mere sloganeering is valid when contradicted by actions and behaviours, as Beijing's "island-building" efforts in the South China Sea have been commonly perceived. Moreover, China's relations with the Philippines are described as having a deficit of soft power with a "net trust rating of minus 24 per cent" (Hodge, 2016). So what is to be done to tilt the balance of BRI toward a more harmonious dynamic?

The prescription would include a greater dose of harmony (he), the meaning of which in Chinese classical thought is much more this-worldly and complex than idealistic, as commonly understood in the West. Harmony in Chinese classical thought comes across as a dynamic and transformative principle that includes discord within the diverse elements that come together. Here it displays a commonality with systems thinking. In systems theory, discord or conflict - if it does not overwhelm the socio-political system's ability to cope-renders society (be it domestic or international) more robust and resilient (see Dellios \& Ferguson, 2013, p. 96). The harmony of opposites, rather than clash, is readily seen in the universal emblem of Chinese culture, the yin-yang symbol. Both the yin and the yang retain their properties, but with each being part of the other there is a mutuality of being and of interests. This goes back to the interdependence arising from the concept of ren. Much of Chinese foreign policy is likewise based on shaping individual, nuanced relationships that allow complementary flows to evolve within qualitative frameworks that go beyond mutual interest: hence the PRC deploys of a range of friendship, friendly, good-neighbourly and strategic-partnership terminologies in its treaties and international agreements (Digeser, 2016; Koschut \& Oelsner, 2014; Devere, 2014).

\section{Balancing Silk Roads of Development}

The headquarters of the United Nations Educational, Scientific and Cultural Organization (UNESCO) in Paris was chosen for the launch for the current leadership's developmental strategy. There, in March 2014, President Xi Jinping articulated a "Chinese Dream" that included cultural diversity in the global order (CCTV, 2014). The economic and financial underpinnings of the Chinese Dream have taken the form of the Belt and Road Initiative. It may have captured the headlines and generated media criticism, but this idea is not outside the scope of Chinese policy in developing poorer regions. Every year since 2010 China has granted more development loans than the World Bank (Hilpert \& Wacker, 2015). According to China's 2014 foreign aid white paper, the PRC provided $\$ 14.41$ billion of aid in three forms - grants, interest-free loans and concessional loans - to 121 countries in the three-year period 2010-12 (State Council Information Office, 2014). Moreover, Beijing has pledged to invest over a trillion dollars worldwide by 2025 (Shambaugh, 2015, p. 101). 
Unintended outcomes from accelerated infrastructure, industrial and economic development, however, will need careful management. Poor regions with limited connectively to regional and global processes will gain access to the benefits of trade, investment and modernization. However, they may also suffer from negative "flows" including intensified pollution, trafficking of illicit goods, increasing flows by transnational organized crime networks, economic and cultural dislocation, as well as intensified disease vectors. The Bangladesh-China-India-Myanmar Economic Corridor (BCIM-EC) will provide economic benefits to poorer and remote communities between Kunming and Kolkata, but may also provide new routes for illicit drugs (methamphetamines and opiates), increase non-documented labour movements, deepen competition among manufacturing industries in different countries, enlarge trade deficits in weaker economies, intensify environmental destruction (only partly controlled by environmental impact assessments), spread diseases such as AIDS along new transport routes, and increase urbanization pressures (Sajjanhar, 2016; Geall, 2016).

Likewise, the China-Pakistan Economic Corridor (CPEC) — announced by President Xi Jinping during a visit to Islamabad in April 2015-is not without its controversies. The project was viewed as having been "rapidly institutionalized" with many MOUs being signed with a focus on "the power and transportation sectors and involving Chinese investment to the tune of US $\$ 46$ billion" by 2030 (Uberoi, 2016). Several major road projects lead from Kashgar in China through Kashmir, Pakistan's tribal areas and then troubled Balochistan down to Gwadar port on Pakistan's southwest coast. It therefore links onto the Maritime Silk Road project and the strategic "string of pearls" agenda whereby Chinese ships (merchant and naval) can gain ready access to Indian Ocean ports. India therefore has been critical of CPEC, seeing it as entrenching China's role in the Indian Ocean, supporting Pakistan's claims to disputed areas of Kashmir, and undermining India's own developmental project running from Chabahar in Iran to Central Asia (Zaidi, 2016; Brewster, 2016). Expanded investment in Balochistan (Western Pakistan) may intensify the view that locals do not benefit proportionately from such megaprojects unless inclusive growth is generated fairly rapidly. The current insurgency, being led by the United Baloch Army for over a decade, may become a wider security issue hindering national development, leading to a more heavy-handed police or military response (Economist, 2015). Once again, CPEC needs to manage a wide number of political and development issues to avoid such dilemmas.

Both these corridors show the need to factor in inclusive growth into these projects at an early stage. "Inclusive growth" is a set of developmental orientations that has been developed extensively by the Asian Development Bank (ADB), which has had its own difficulties in mitigating the impact of large development projects. Along with the ADB, the World Bank, the Inter-American Development Bank, the Organization for Economic Cooperation and Development (OECD) and UNDP have begun to focus on inclusive development (IDB, 2015) with the following features:

\section{- $\quad$ All members of society participate and contribute}

- Particular emphasis on the poor and disadvantaged being able to participate in growth (making inclusive growth "nondiscriminatory")

- Reducing inequality in its non-income dimensions of well-being. This helps promote economic opportunities, including education, health, nutrition and social integration. It is the "disadvantage-reducing" characteristic of inclusive growth

- $\quad$ Positive per capita GDP growth rates

- A growth in the income of people belonging to disadvantaged groups, such as women, ethnic minorities, or those living in poor areas

- Improvements in education, mortality rates, access to transportation, communications, and basic services - water, electricity, waste management (Klassen, 2010)

The corridors highlight another issue for BRI as a whole. Many countries engaging in these projects have political instability, patterns of transnational terrorism or organized crime, and long-term social inequality. Several countries along these corridors, including Tajikistan, the Kyrgyz Republic, Uzbekistan, Bangladesh and Pakistan have low GDP per capita (between $\$ 2,980$ and $\$ 6,514$ in PPP terms), low Human Development Index figures (ranking below 108th globally), have problems in maintaining internal peace and cohesive governance, and have limited environmental stewardship, as collated in Yale University's Environmental Performance Index (see Table 1). Although some of these indices can be challenged as Western-centred and somewhat arbitrary in construction, they do indicate that these states are beset by a wide range of developmental and security issues. They thus welcome investment, aid and trade, but may have problems in both governing and absorbing these flows in a sustainable way. 
Table 1. BRI Partner Countries with limited development and governance indictors*

\begin{tabular}{lllllll}
\hline Country & GDP per Capita (PPP) & HDI (2016) & HDI Rank (2016) & Peace Index Rank & Fragile States index & EPI Rank \\
\hline Tajikistan & $\$ 2,980$ & 0.627 & 129 & 122 & 81.8 High Warning & 72 \\
Kyrgyzstan & $\$ 3,551$ & 0.664 & 120 & 124 & 80.3 High Warning & 71 \\
Uzbekistan & $\$ 6,514$ & 0.701 & 108 & 109 & 81.5 High Warning & 118 \\
Bangladesh & $\$ 3,580$ & 0.579 & 140 & 83 & 89.1 High Warning & 173 \\
Pakistan & $\$ 5,249$ & 0.550 & 148 & 153 & 98.9 Alert & 144 \\
\hline Note. ${ }^{*}$ Composite indicators collated from World Bank, 2016; Jahan et al., 2016; IEP, 2016; Hsu et al., 2016; Messner et al., 2017. EPI = the \\
Environmental Performance Index.
\end{tabular}

Attendant risks for China include "social confrontations between local and Chinese workers, environmental degradation issues as well as disputes over an apparent lack of corporate social responsibilities on the part of Chinese firms" (Arduino, 2016). Moreover, the PRC's engagement in overseas projects has already led to debates on the role of Chinese Private Security Companies (PSCs) abroad and to the selective use of the Chinese armed forces in protecting China's wider interests; for example, the transfer of Chinese citizens from crises in Libya and Yemen (Arduino, 2016; Liu, 2015). In the Yemen case, other foreign nationals were also rescued.

Historically, the PRC has found the status of investments in Myanmar, Sudan, Mongolia, Afghanistan, Tajikistan and even Australia complicated by political and social risk. This means that China may well need to further extend its current MOOTW (military operations other than war) doctrine to think about ensuring human security along these corridors with the minimal use of force, whether by national armies, local police or private military contractors (State Council Information Office, 2013). Likewise, to ensure positive human outcomes, dialogue with a wide range of societal and civil society groups is needed beyond corporate and inter-state agreements. This would meet one of the Chinese military's "New Historic Missions" propagated since 2004 (Mulvenon, 2009): that of helping to maintain world peace. This is compatible with China's rising profile in peacekeeping: it plans to create a standby peacekeeping force of 8,000 , contributes approximately $6.6 \%$ of the UN peacekeeping budget, and deployed over 33,000 troops on 24 peacekeeping missions since 1990, with operations in the Democratic Republic of Congo, Liberia, Lebanon, Sudan, Mali and South Sudan (Bwanbale, 2016). By the end of 2015, China became the ninth largest contributor to peacekeeping operations worldwide, with 161 police, 36 UN military experts, and 2,882 troops engaged (Danner, 2016). Current BRI projects, with operations across zones with transnational and transboundary security challenges, may encourage the PRC to extend these operations - for example, as a result of deepening concerns over Afghanistan's stability and African security.

\section{Conclusion: Sustaining Human Security}

In the transition from Chinese Dream to a Belt and Road reality that accords with the dream, care needs to be taken to encourage a sustainable approach and "not to impose on others what you yourself do not desire", as Confucius taught.

While the BRI has the potential for cultivating cultural openness and a deeper understanding of development as based on mutuality, work still lies ahead. One area is to remedy the "trust deficit" of state-provoked behaviours that are seen in win-lose terms or a pseudo "win-win", with China having a higher percentage of "winning" compared to the "crumbs from the table" for its partners. Patterns of inclusive growth and societal dialogue need to be engaged at an early stage, allowing the management of negative consequences of rapid development.

If China takes a decidedly Confucian ethical turn in the Belt and Road Initiative, then this will deserve the status of a historic grand project of international dimensions, like the tribute system before it. Unlike the past, however, it would not be hierarchical political relations that would characterize the system but the ethical and system-supporting ones that describe a state's responsibilities. The state-based system would need to be responsive the societal and ecological needs of human security. The new silk roads of the present century carry the physical promise of development, but it is the ideational component that seeks to be cultivated. Chinese elites are well equipped with a Confucian heritage that can advance the cause of human security as a key component of silk roads development. Only then would the massive expenditures and herculean engineering feats find a welcome mat amongst local communities.

\section{References}

Abt, K. (2013). A Critique of Japan's Official Discourse on Human Security. Thesis (PhD), Bond University. Retrieved from http://epublications.bond.edu.au/cgi/viewcontent.cgi?article=1160\&context=theses

Acharya, A., Singhdeo. S. K., \& Rajaretnam, M. (2011). Human Security: From Concept to Practice-Case Studies from Northeast India and Orissa. Singapore: World Scientific Series on Human Security, 1. 
AIIB. (2016). Environmental and Social Framework. Retrieved from https://www.aiib.org/en/policiesstrategies/_download/environment-framework/20160226043633542.pdf

Albert, E. (2014). The Shanghai Cooperation Organization. Council on Foreign Affairs Backgrounders. Retrieved from http://www.cfr.org/china/shanghai-cooperation-organization/p10883

Albert, E. (2016). Competition in the Indian Ocean. Council on Foreign Relations Backgrounders. Retrieved from http://www.cfr.org/regional-security/competition-indian-ocean/p37201

Ames, R., \& Hall, D. L. (2000). Focusing the Familiar: A Translation and Philosophical Interpretation of the Zhongyong. Honolulu: University of Hawaii Press.

AP. (2016). Rodrigo Duterte Flags Return to Scarborough Shoal. The Australian. Retrieved from http://www.theaustralian.com.au/news/world/rodrigo-duterte-flags-return-to-scarborough-shoal/news-story/ 36206d33216bd28f7db8a6f028d51846

Arduino, A. (2016). Security in One Belt One Road: Singapore's Role in Training Expertise. RSIS Commentary no. 125.

Bell, D. A. (2015). The China Model: Political Meritocracy and the Limits of Democracy. Princeton NJ: Princeton University Press.

Bittner, P. (2016). China, Russia, Mongolia Sign Long-Awaited Economic Partnership Agreement. The Diplomat. Retrieved from http:/thediplomat.com/2016/06/china-russia-mongolia-sign-long-awaited-economic-partnership-agreement/

Breslin, S. (2014). Debating Human Security in China: Towards Discursive Power? Journal of Contemporary Asia, 45(2), 1-23. http://dx.doi.org/10.1080/00472336.2014.907926

Brewster, D. (2016). Chabahar: India's New Move in the Great Indian Port Race. The Interpreter. Retrieved from

http://www.lowyinterpreter.org/post/2016/05/31/Chabahar-Indias-new-move-in-the-great-Indian-Ocean-port -race.aspx

Bwambale, T. (2016). China to Expand Peacekeeping Role in Africa. New Vision. Retrieved from http://www.newvision.co.ug/new_vision/news/1433624/china-expand-peacekeeping-role-africa

Caballero-Anthony, M. (2015). Community Security: Human Security at 21. Contemporary Politics, 21(1), 53-69. http://dx.doi.org/10.1080/13569775.2014.994812

CCTV. (2014). Xi Talks about Peace, Diversity, Chinese Dream at UNESCO. Retrieved from http://english.cntv.cn/2014/03/27/VIDE1395931443766683.shtml

Chen, Y., Li, Z., \& Li, W. et al. (2016). Water and Ecological Security: Dealing with Hydroclimatic Challenges at the Heart of China's Silk Road. Environmental Earth Sciences, 75(10), 1-10. https://doi.org/10.1007/s12665-016-5385-z

Clark, H. (2016). Vietnam Careful, Not Jubilant after South China Sea Ruling against China. Huff Post. Retrieved from http://www.huffingtonpost.com/helen_clark/vietnam-south-china-sea-ruling_b_11022864.html

Confucius. (1979). The Analects. (trans. D. C. Lau.) Harmondsworth: Penguin.

Dallmayr, F. (2003). Confucianism and the Public Sphere: Five Relationships Plus One? Dao: A Journal of Comparative Philosophy, 2(2), 193-212.

Danner, L. K. (2016). Rising Assertiveness versus Peaceful Development: Making Sense of China's Ambivalent International Behaviour. Culture Mandala, 12(1), 23-44. Retrieved from http://www.international-relations.com/CM2016/3-China-Rising-Assertiveness-Peaceful-Development-Dan ner.pdf

De Bary, W. T., \& Bloom, I. (1999). comp. Sources of Chinese Tradition, 1. New York: Columbia University Press.

Dellios, R. (2016). South China Sea: Why Aid will Trump Islands. The Asia \& the Pacific Policy Society (APPS) Policy Forum. Retrieved from http://www.policyforum.net/south-china-sea-aid-will-trump-islands/

Dellios, R., \& Ferguson, R. J. (2013). China's Quest for Global Order: From Peaceful Rise to Harmonious World. Lanham Md: Lexington Books.

Devere, H. (2014). Friendship in International Treaties. In S. Koschut \& A. Oelsner (Eds.), Friendship and 
International Relations (pp. 182-200). Houndmills: Palgrave Macmillan. https://doi.org/10.1057/9781137396341_10

Digeser, P. E. (2016). Friendship Reconsidered: What it Mean and How it Matters to Politics. New York: Columbia University Press.

Dong, C., Davis, M., Li, P., \& Yu, S. (2016). One Belt One Road: China's New Outbound Trade Initiative: $\begin{array}{lllll}\text { Regulatory } \quad \text { Update. } & \text { Piper. } & \text { Retrieved }\end{array}$ https:/www.dlapiper.com/en/australia/insights/publications/2016/01/chinas-new-outbound-trade-initiative/

Economist. $\quad$ (2015). Dark $\quad$ Corridor. Retrieved from http:/www.economist.com/news/asia/21653657-conflict-balochistan-must-be-resolved-trade-corridor-betw een-pakistan-and-china-bring

El-Bassel, N., Gilbert, L., Shaw, S. A., Mergenova, G., Terlikbayeva, A., \& Primbetova, S. et al. (2016). The Silk Road Health Project: How Mobility and Migration Status Influence HIV Risks among Male Migrant Workers in Central Asia. PLoS ONE, 11(3), 1-16. https://doi.org/10.1371/journal.pone.0151278

Emmers, R. (2007). International Regime Building in ASEAN: Cooperation against the Illicit Trafficking and Abuse of Drugs. Contemporary Southeast Asia, 29(3), 506-525. https://doi.org/10.1355/CS29-3G

Fallon, T. (2015). The New Silk Road: Xi Jinping's Grand Strategy for Eurasia. American Foreign Policy Interests, 37(3), 140-147. http://dx.doi.org/10.1080/10803920.2015.1056682

Ferguson, R. J., \& Dellios, R. (2017). The Politics and Philosophy of Chinese Power: The Timeless and the Timely. Lanham Md: Lexington Books.

Freiman, I., Ward, N., \& Nair, N. (2016). Belt and Road Insights. Berwin Leighton Paisner. Retrieved from http:/www.blplaw.com/expert-legal-insights/articles/belt-and-road-insights-april-2016

Geall, S. (2016). Map: China's Massive Overseas Investment Plans Charted. The Third Pole. Retrieved from https:/www.thethirdpole.net/2016/02/22/map-chinas-massive-overseas-investment-plans-charted/

Grieger, G. (2016). One Belt, One Road (OBOR): China's Regional Integration Initiative. European Parliament Briefing. $\quad$ Retrieved from http://www.europarl.europa.eu/RegData/etudes/BRIE/2016/586608/EPRS_BRI(2016)586608_EN.pdf

Hamashita, T. (2003). Tribute and Treaties, Ch. 1. In G. Arrighi, T. Hamashita, \& M. Selde (Eds.), The Resurgence of East Asia: 500, 150 and 50 Year Perspectives. London: Routledge.

Hilpert, H. G., \& Wacker, G. (2015). Geoeconomics Meets Geopolitics: China's New Economic and Foreign Policy Initiatives. SWP Comments 33, German Institute for International and Security Affairs.

Hodge, A. (2016). Has Beijing Put the Soft Word on Philippines' Rodrigo Duterte? The Australian. Retrieved from

http://www.theaustralian.com.au/news/world/has-beijing-put-the-soft-word-on-philippines-rodrigo-duterte/n ews-story/50cb527090253fca06a684b51dfc493f

Hong Kong Trade Development Council. (HKTDC, 2016). The Belt and Road Initiative. HKTDC Research. Retrieved

from http://china-trade-research.hktdc.com/business-news/article/One-Belt-One-Road/The-Belt-and-Road-Initiati ve/obor/en/1/1X000000/1X0A36B7.htm

Hsu, A. et al. (2016). Environmental Performance Index. New Haven, CT: Yale University. https://doi.org/10.1002/9781118445112.stat03789.pub2

Human Security Unit. (2016). Human Security Handbook: An Integrated Approach for the Realization of Sustainable Development Goals and the Priority Areas of the International Community and the United Nations System. NY Human Security Unit. Retrieved from www.un.org/humansecurity/sites/www.un.org.humansecurity/files/hs_handbook_03.pdf

IDB Sustainability Report 2014. (2015). Washington DC: Inter-American Development Bank. Retrieved from https://publications.iadb.org/bitstream/handle/11319/6848/Inter-American-Development-Bank-Sustainabilit y-Report-2014.pdf?sequence $=1$

IEP Global Peace Index 2016: Ten Years of Measuring Peace. (2016). Sydney, N. Y., Brussels \& Mexico City: Institute for Economics and Peace. http://visionofhumanity.org/app/uploads/2017/02/GPI-2016-Report_2.pdf 
Jahan, S. et al. (2016). Human Development Report 2016: Human Development Report for Everyone (2016). N.Y.: United Nations Development Programme. Retrieved from http://hdr.undp.org/sites/default/files/2016_human_development_report.pdf

JICA Japan's ODA. (2016). JICA Annual Report. Japan International Cooperation Agency. Retrieved from https://www.jica.go.jp/english/publications/reports/annual/2016/c8h0vm0000aj21oz-att/2016_05.pdf

Klassen, S. (2010). Measuring and Monitoring Inclusive Growth: Multiple Definitions, Open Questions, and Some Constructive Proposals. Manila: Asian Development Bank. Retrieved from https://www.adb.org/sites/default/files/publication/28492/adb-wp12-measuring-inclusive-growth.pdf

Koschut, S., \& Oelsner, A. (2014). Friendship and International Relations. Houndmills: Palgrave Macmillan. https://doi.org/10.1057/9781137396341

Kynge, J. (2016). How the Silk Road Plans Will Be Financed. Financial Times. Retrieved from https://next.ft.com/content/e83ced94-0bd8-11e6-9456-444ab5211a2f

Len, C. (2015). China's 21st Century Maritime Silk Road Initiative, Energy Security and SLOC Access. Maritime Affairs: Journal of the National Maritime Foundation of India, 11(1), 1-18. http://dx.doi.org/10.1080/09733159.2015.1025535

Lewis, M. E. (2009). China's Cosmopolitan Empire: The Tang Dynasty. Cambridge MA: Harvard University Press.

Li, P., Qian, H., \& Zhou, W. (2017). Finding Harmony between the Environment and Humanity: An Introduction to the Thematic Issue of the Silk Road. Environmental Earth Science, 76(3), 1-4. https://doi.org/10.1007/s12665-017-6428-9

Li, P., Qian, H., Howard, K., \& Wu, J. (2015). Building a New and Sustainable "Silk Road Economic Belt". Environmental Earth Science, 74(10), 7267-7240. https://doi.org/10.1007/s12665-015-4739-2

Lijun, S. (2006). China-ASEAN Cooperation among Illicit Drugs from the Golden Triangle. Asian Perspective, 30(2), 97-126. Retrieved from http://www.asianperspective.org/articles/v30n2-d.pdf

Liu, X. (2015). Private Security Companies Struggle to Go Abroad Due to Legal Restrictions. Global Times. Retrieved from http://www.globaltimes.cn/content/960208.shtml

Lizee, P. (2002). Human Security in Vietnam, Laos, and Cambodia. Contemporary Southeast Asia, 24(3), 509-537. https://doi.org/10.1355/CS24-3D

Mencius. (1988). Mencius. (trans. D. C. Lau). Harmondsworth: Penguin.

Messner, J. J. et al. (2017). Fragile States Index 2017. Washington D.C.: Fund for Peace. Retrieved from http://reliefweb.int/sites/reliefweb.int/files/resources/951171705-Fragile-States-Index-Annual-Report-2017. pdf

Millward, J. A. (2007). Eurasian Crossroads: A History of Xinjiang. N.Y.: Colombia University Press.

MOFA Priority Policy for Development Cooperation. (2015). Japan: International Cooperation Bureau, Ministry of Foreign Affairs. Retrieved from http://www.mofa.go.jp/files/000082915.pdf

Morton, W. S., \& Lewis, C. M. (2004). China: Its History and Culture. New York: McGraw-Hill.

Mulvenon, J. (2009). Chairman Hu and the PLA's "New Historic Missions". China Leadership Monitor, (27), Hoover Institution. Retrieved from http://media.hoover.org/sites/default/files/documents/CLM27JM.pdf

National Development and Reform Commission (NDRC), Ministry of Foreign Affairs, and Ministry of Commerce of the PRC, with State Council authorization. (2015). Vision and Actions on Jointly Building Silk Road Economic Belt and 21st-Century Maritime Silk Road (1st ed.). Retrieved from http://www.fmprc.gov.cn/mfa_eng/topics_665678/xjpcxbayzlt2015nnh/t1249618.shtml

NBS. (2016). Water Resources for Xinjiang. National Data-National Bureau of Statics of China. Retrieved from http://data.stats.gov.cn/english/easyquery.htm?cn=E0103

Newman, E. (2016). Human Security: Reconciling Critical Aspirations with Political "Realities". The British Journal of Criminology, 56(6), 1165-1183. https://doi.org/10.1093/bjc/azw016

Okubo, S., \& Shelley, L. (2011). Human Security, Transnational Crime and Human Trafficking-Asian and Western Perspectives. London: Routledge.

PRC Full Text: China's Policies on Asia-Pacific Security Cooperation. (2017). State Council Information Office 
White Paper. Retrieved from http://news.xinhuanet.com/english/china/2017-01/11/c_135973695.htm

PRC Vision for Maritime Cooperation under the Belt and Road Initiative. (2017). National Development and Reform Commission (NDRC) and the State Oceanic Administration (SOA), Xinhua.

Preston, F., Bailey, R., Bradley, S., Wei, J., \& Zhao, C. (2016). Navigating the New Normal: China and Global Resource Governance. Development Research Centre of the State Council and Chatham House. Retrieved from https://asiaviewersdotcom.files.wordpress.com/2015/11/china_globalresource_governance_2016.pdf

Rambler News Service. (2016). EEU, SCO Preparing "Most Ambitious Trade Agreement". Russia \& India Report. Retrieved from http://in.rbth.com/economics/finance/2016/03/03/eeu-sco-preparing-most-ambitious-trade-agreement_5726 85

Ren, X. (2016). Human Security: China's Discourses and Experience. Journal of Human Security, 12(1). https://doi.org/10.12924/johs2016.12010112

Reuters. (2016). Duterte Clarifies "Separation" Comments, Says Trade Ties Between Philippines and US will Stay. ABC News. Retrieved from http://www.abc.net.au/news/2016-10-21/duterte-says-us-has-lost-aligns-philippines-with-china/7952628

Reuters. (2017). China, Philippines Agree to Cooperate on 30 Projects worth $\$ 3.7$ Billion. CNBC. Retrieved from

http://www.cnbc.com/2017/01/23/china-philippines-agree-to-cooperate-on-30-projects-worth-37-billion.ht $\mathrm{ml}$

Sajjanhar, A. (2016). Understand BCIM Economic Corridor and India's Response. ORF Issue Brief, 145. Retrieved from http://www.orfonline.org/wp-content/uploads/2016/06/ORF_IssueBrief_147.pdf

Schirch, L. (2015). Handbook on Human Security: A Civil-Military-Police Curriculum. The Hague: Alliance for Peacebuilding, GPPAC, Kroc Institute.

Shambaugh, D. (2015). China's Soft-Power Push: The Search for Respect. Foreign Affairs. Retrieved from https://www.foreignaffairs.com/articles/china/2015-06-16/china-s-soft-power-push

Shevchenko, N. (2013). Rebalancing Human Security: The European Union as a Driving Force. Atlantic-Community.org. Retrieved from http://www.atlantic-community.org/-/rebalancing-human-security-the-european-union-as-a-driving-force

Snelder, J. (2016). Will One Belt One Road Pay Off? The Interpreter. Retrieved from http://www.lowyinterpreter.org/post/2016/05/19/Will-One-Belt-One-Road-pay-off.aspx

South China Morning Post (SCMP). (2016). Xi tells Duterte that Scarborough Shoal will stay open to Philippine fishermen. Retrieved from http://www.scmp.com/news/china/diplomacy-defence/article/2047747/xi-tells-duterte-scarborough-shoal-wi 11-stay-open

State Council Information Office, PRC. (2013). The Diversified Employment of China's Armed Forces. Retrieved from http://news.xinhuanet.com/english/china/2013-04/16/c_132312681.htm

State Council Information Office, PRC. (2014). China's Foreign Aid. Retrieved from http://news.xinhuanet.com/english/china/2014-07/10/c_133474011.htm

Supriyanto, R. A. (2016). A View from Indonesia. National Commentaries. Retrieved from http://www.theasanforum.org/a-view-from-indonesia/

Supriyanto, R. A. (2016). Breaking the Silence: Indonesia Vs China in the Natuna Islands. The Diplomat. Retrieved

from http://thediplomat.com/2016/03/breaking-the-silence-indonesia-vs-china-in-the-natuna-islands/

Teh, B. (2012). Human Security: Securing East Asia's Future. Netherlands: Springer.

Thede, N. (2008). Human Security, Democracy, and Development in the Americas: The Washington Consensus Redux? Canadian Journal of Latin American and Caribbean Studies, 33(65), 33-56. http://dx.doi.org/10.1080/08263663.2008.10816939

Tiquia, L. (2015). Ma "Where To, Philippines". The Manila Times. Retrieved from http://www.manilatimes.net/where-to-philippines/196237/

Tweed, D. (2016). China's Silk Road: Ancient Routes Carry a Nation's Influence West. QuickTake, Bloomberg. 
Retrieved from https://www.bloomberg.com/quicktake/china-s-silk-road

Tzifakis, N. (2011). Problematizing Human Security: A General/Contextual Conceptual Approach. Southeast European and Black Sea Studies, 11(4), 353-368. http://dx.doi.org/10.1080/14683857.2011.632539

Uberoi, P. (2016). Problems and Prospects of the BCIM Economic Corridor. China Report, 52(1), 19-44. https://doi.org/10.1177/0009445515613868

UN General Assembly. (2012). Resolution 66/290 on Human Security. Retrieved from http://www.un.org/humansecurity/sites/www.un.org.humansecurity/files/hsu\%20documents/GA\%20Resolut ions.pdf

Womack, B. (2012). Asymmetry and China's Tribute System. The Chinese Journal of International Politics, 5 , 37-54. https://doi.org/10.1093/cjip/pos003

Wong, L. F. (2007). China-ASEAN and Japan-ASEAN Relations during the Post-Cold War Era. Chinese Journal of International Politics, 1(3), 373-404. https://doi.org/10.1093/cjip/pom003

World Bank. (2016). GDP Per Capita, PPP (current international \$). Retrieved from http://data.worldbank.org/indicator/NY.GDP.PCAP.PP.CD

Wu, G. (2012). China's Challenges to Human Security: Foreign Relations and Global Implications. London: Routledge.

Yan, X. (2011). Ancient Chinese Thought, Modern Chinese Power (In D. A. Bell \& S. Zhe, eds.; trans. E. Ryden). Princeton: Princeton University Press.

Zaidi, S. A. (2016). The New Game Changer in Pakistan. The Hindu. Eds. D. A. Bell \& S. Zhe, trans. E. Ryden. Retrieved http://www.thehindu.com/opinion/lead/chinapakistan-economic-corridor-the-new-game-changer-in-pakistan /article8656498.ece

Zhang, F. (2010). The Tianxia System: World Order in a Chinese Utopia. China Heritage Quarterly, (21). Retrieved from http://www.chinaheritagequarterly.org/tien-hsia.php?searchterm=021_utopia.inc\&issue=021

Zhao, T. (2006). Rethinking Empire from a Chinese Concept: "All-under-Heaven” (Tian-xia). Social Identities, 12(1), 29-41. https://doi.org/10.1080/13504630600555559

\section{Notes}

Note 1. The pre-eminence of the Chinese emperor in tribute relations was the implication but not always the reality when pragmatism or military setbacks caused China "to recognize peers and equals, especially when the state involved was a distant and powerful one-Rome, Persia or Russia" (Dellios \& Ferguson, 2013, p. 51). See also Womack, 2012; Hamashita, 2003.

Note 2. Possible tensions between the Central Asian projects within the new silk roads and the Russian-led EEU agenda were partly resolved by dialogue through 2015-2016. Coordination of EEU and the new silk roads has begun with efforts to direct investment towards northern transcontinental rail and energy linkages, thereby enhancing connectivity among Russia, Kazakhstan, Mongolia and China as a new Continental Economic Partnership (Rambler News Service, 2016; Bittner, 2016; Albert, 2014). 


\section{Appendix A}

\section{The Silk Roads "Belt and Road Initiative"}

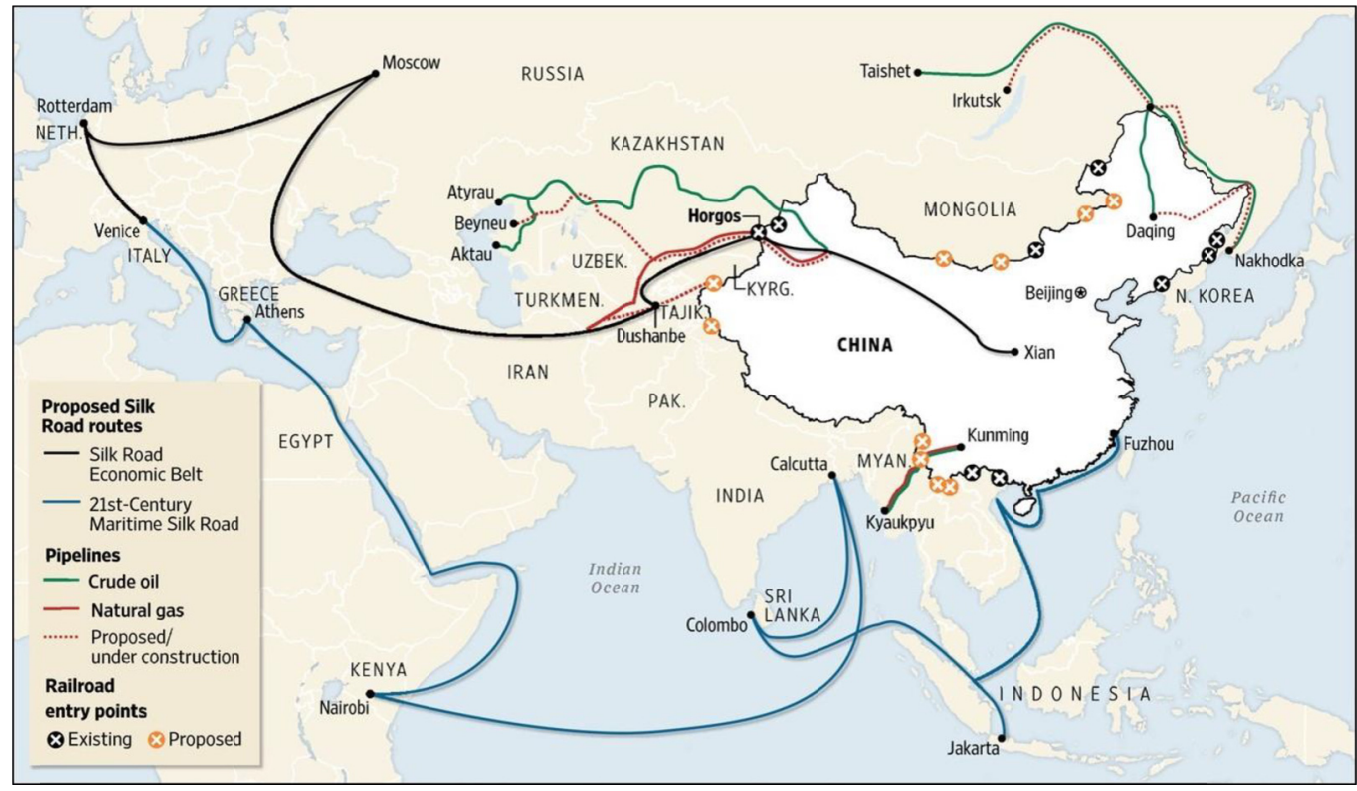

Source:

The

Wall

Street

Journal

(2014).

Retrieved

from

http://www.wsj.com/articles/chinas-new-trade-routes-center-it-on-geopolitical-map-1415559290

\section{Appendix B}

\section{The Six Economic Corridors}

The Belt and Road Initiative: Six Economic Corridors Spanning Asia, Europe and Africa

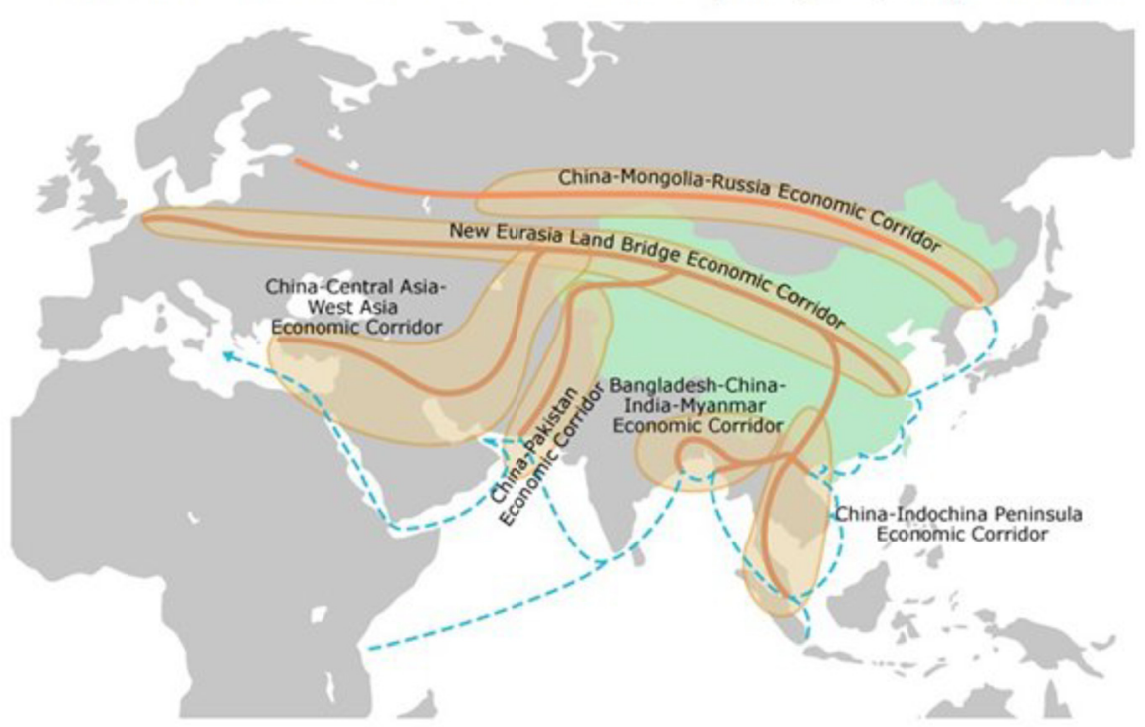

Source: Hong Kong Trade Development Council. (HKTDC, 2016, January 21). “The Belt and Road Initiative”. HKTDC Research. Retrieved from

http://china-trade-research.hktdc.com/business-news/article/One-Belt-One-Road/The-Belt-and-Road-Initiative/obor/en/1/1X000000/1X0A36 B7.htm

\section{Copyrights}

Copyright for this article is retained by the author(s), with first publication rights granted to the journal.

This is an open-access article distributed under the terms and conditions of the Creative Commons Attribution license (http://creativecommons.org/licenses/by/4.0/). 